\title{
Assessment on knowledge on Genetic Counseling among Antenatal mothers at Melmaruvathur Adhiparasakthi Institute of Medical Sciences.
}

\author{
*Mrs.Umamaheswari.R
}

\section{Abstract:}

Objectives: To assess the level of knowledge on genetic counseling among antenatal mothers. Methods: Descriptive research design was adopted for the study. Result: The Study finding showed that $20 \%$ of mothers had inadequate knowledge, $76 \%$ of mothers had moderate and $4 \%$ of mothers had adequate knowledge about the genetic counseling. Conclusion: The present study indicated that most of the antenatal mothers were having only moderate knowledge about the genetic counseling. So the health care professionals should be aware of genetic disorders and its management and should create an awareness of genetic counseling among the antenatal mothers.

Keywords: Genetic disorders, Genetic counseling, Antenatal mothers.

\section{INTRODUCTION}

The science of genetics is concerned with disease processes that can be passed from one generation to the next or that are related to a defect in chromosomal reproduction. The range of genetic problems is considerable. Some are incompatible with life; others may cause little disruption to the life process. Genetic counseling integrates family history with available information about the fetus to determine the risk of genetic disease in the fetus. ${ }^{1}$. A family history of genetic disorders, a previous baby affected with a congenital abnormality and leaving childbearing until later years all increase the risk of giving birth to an abnormal child.
For such couples, referral for genetic counseling will help them to decide what is best for them. ${ }^{2}$

The risk of having a child with a genetic defect is something that only the couple can decide whether to take or not. ${ }^{2}$ Nearly $3 \%$ of newborns have major congenital anomaly. Usually genetic factors are responsible. Chromosomal abnormalities are observed in majority of all first trimester miscarriages and about $5 \%$ of all stillborns. So the antenatal mothers play an essential role in preventing genetic disorders. So the researcher has planned to know the level of knowledge on genetic counseling among antenatal mothers. ${ }^{3}$ 


\section{OBJECTIVES OF THE STUDY:}

1. To assess the level of knowledge on genetic counseling among antenatal mothers.

2. To find out association between the knowledge of antenatal mothers on genetic counseling with selected demographic variables.

\section{METHODOLOGY:}

Descriptive research design was adopted for the study. The study was conducted at antenatal ward in Melmaruvathur Adhiparaskthi Institute of Medical Science and Research, Melmaruvathur .A total of 30 samples were selected by Convenient sampling technique and data were selected by using questionnaire method. The questionnaire consisted of 20 multiple choice questions related to knowledge on genetic counseling among antenatal mothers.

\section{RESULT:}

Assessment of knowledge on Genetic Counseling among antenatal mothers.

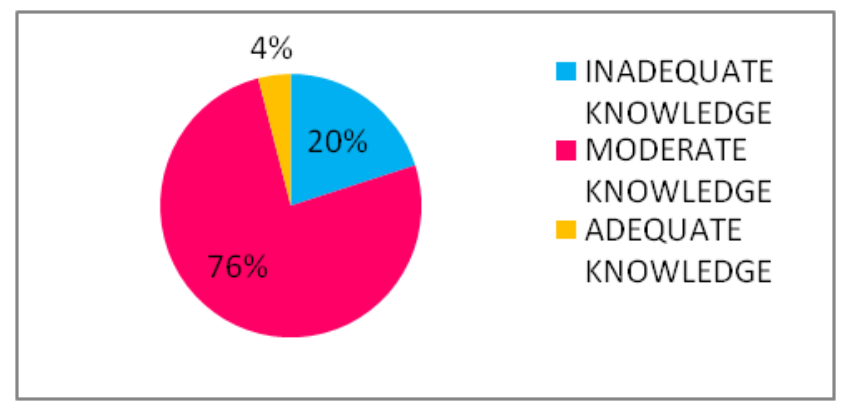

\section{DISCUSSION:}

The first objective was to assess the level of knowledge on genetic counseling among antenatal mothers was assessed through the using questionnaire method. Data showed that $20 \%$ of mothers had inadequate knowledge, $76 \%$ of mothers had moderately adequate knowledge and $4 \%$ of mothers had adequate knowledge.

The second objective was to find out association between the knowledge of antenatal mothers on genetic counseling with selected demographic variables. The study findings shows that there is no association between the knowledge of antenatal mothers on genetic counseling with selected demographic variables.

\section{RECOMMENDATIONS:}

- A similar study can be conducted with a large sample among antenatal mothers .

- A comparative study can be conducted with a large sample among antenatal mothers in urban and rural areas.

- An effectiveness study can be conducted on teaching programme on genetic counseling among antenatal mothers.

\section{CONCLUSION:}

The present study indicated that most of the antenatal mothers got only moderate knowledge about the genetic counseling. 
So the health care professionals should be aware of genetic disorders and its management and should create an awareness of genetic counseling among the antenatal mothers.

\section{REFERENCES:}

- A.V.Raman,"Maternity Nursing", 19th edition , New Delhi: Wolters Kluwer ,2011,Page.No:130-147

- Myles, "Textbook of Midwives",15 th edition ,Elsevier Publication, 2007,Page no :173174

- D.C.Dutta, "Textbook of Obstertics",6 $6^{\text {th }}$ edition ,2006, Calcutta: New central Book agency (P) Ltd, Page no:212-240
- Gupta.S," The Short Text book of Pediatrics" 9 ${ }^{\text {th }}$ edition, 1998 ,Jaypee brothers,NewDelhi

- Basavathappa,"NursingResearch",2 005, Jaypee brothers,NewDelhi.

- D.C.Dutta, Textbook of Gynaecology, $4^{\text {th }}$ edition , 2007,Calcutta: New central Book agency (P) Ltd, Page no:212-240

- Bobak M.I,Jenson D.M,"Maternity and Gynecologic care " $5^{\text {th }}$ edition, 1993, St.Louis,Mosby publishers.

\section{Answer key for September - December 2016}

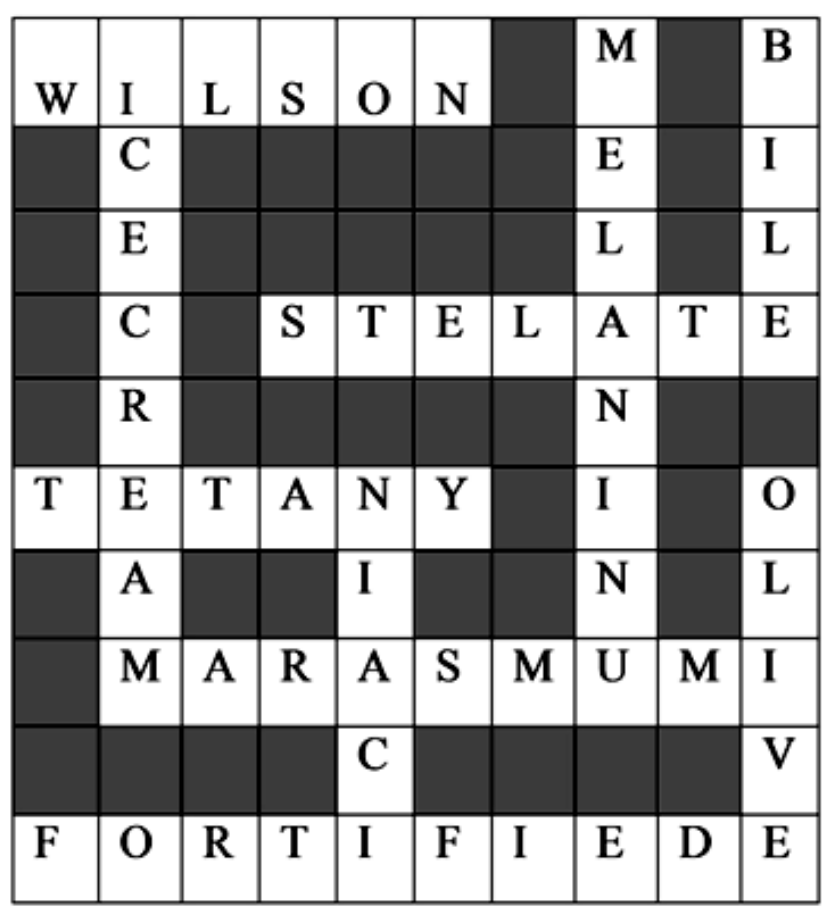

